\title{
Genetic relationships among Arachis species based on AFLP
}

\author{
Marcos A. Gimenes ${ }^{1}$, Catalina R. Lopes ${ }^{1}$ and Jose F.M. Valls ${ }^{2}$ \\ ${ }^{1}$ Departamento de Genética, Universidade Estadual Paulista (UNESP), Rubião Junior, Botucatu, SP, Brazil. \\ ${ }^{2}$ Embrapa Recursos Genéticos e Biotecnologia (CENARGEN) - PqEB, Brasília, DF, Brazil.
}

\begin{abstract}
Amplified Fragment Length Polymorphism (AFLP) was used to establish the genetic relationships among 20 species from seven of the nine sections of genus Arachis. The level of polymorphism among nine accessions of the cultivated peanut, $A$. hypogaea L., was also evaluated. Three combinations of primers were used to amplify the AFLPs. The fragments were separated in $6 \%$ denaturing acrylamide gels. A total of 408 fragments were analyzed. An average of 135.3 fragments per primer combination were scored, and the largest number of fragments was 169 using primer combination Eco RI - ACC / Mse I - CTG, while the lowest was 108, with Eco RI - ACT / Mse I - CTT. In general, the genetic relationships established using AFLPs agreed with the classification established using morphology and crossability data. The results indicated that AFLPs are good markers for establishing the relationships among Arachis species. The polymorphism detected in $A$. hypogaea by this method was higher than the one found with other markers, like RAPDs and RFLPs. However, our data suggest that the polymorphism detected be using AFLP with only three primer combinations is still too low to be used for any kind of genetic study in this species.
\end{abstract}

Key words: AFLP, Arachis, peanut, taxonomic relationship.

Received: March 5, 2002; accepted: July 24, 2002.

\section{Introduction}

The genus Arachis was divided into nine sections by Krapovickas and Gregory (1994). Although those two authors analyzed a large number of accessions of several species, the large number of accessions recently collected broadened the geographic distribution of most sections. New questions about the taxonomic placement and relationships between some species have frequently been raised in this genus, since some accessions show morphological characteristics, which are intermediate between different species. Changes in the taxonomic relationships are likely to happen, when those new accessions are taken into account. If one considers the high probability of new materials being found, to be added to the Arachis germplasm collections, since a relevant effort has been made to broaden this collection, those changes might be quite significant. Thus, a methodology capable of helping to establish the genetic relationships within this genus in a reliable and fast way would be very useful.

Molecular markers have been used to establish taxonomic and phylogenetic relationships in several plant species (Fatokun et al., 1993; Xu and Slleper, 1994; Curtis et al., 1995; Cerry et al., 1996). The phylogenetic relation-

Send correspondence to Marcos A. Gimenes. Departamento de Genética, Universidade Estadual Paulista (UNESP), Rubião Junior, 18618 Botucatu, SP, Brazil. E-mail: gimenes@laser.com.br. ships in the genus Arachis have also been studied using different molecular markers, such as seed protein profiles (Singh et al., 1991; Singh et al., 1994), isoenzymes (Stalker et al., 1994; Maass and Ocampo, 1995; Galgaro et al., 1997), RAPDs (Halward et al., 1991, 1992; Gimenes et al., 2000), and RFLPs (Kochert et al., 1991; Paik-Ro et al., 1992; Stalker et al., 1995; Kochert et al., 1996, Galgaro et al., 1998). All those markers have generated information that has been very useful for solving taxonomic and phylogenetic questions in this genus. However, they have some limitations, such as a low level of polymorphism, detection of few loci per assay, requirement of large quantities of relatively pure DNA, high cost, aside from being labor-intensive, time-consuming, offering very poor genetic information due the detection of just one allele per locus, and having a low reproducibility (Jain et al., 1194; Millan et al., 1996, Hill et al., 1996; Paul et al., 1997).

AFLP (Amplified Fragment Length Polymorphism), a PCR-based technique (Vos et al., 1995), seems to overcome many of the limitations of the other molecular markers. AFLP has revealed much more polymorphism than RAPD and RFLP, because it allows a larger number of loci to be sampled in a single assay (10 to 50 polymorphic loci), it is more reliable and easier to score than RAPDs, and requires less time to assay a large number of loci. Our objective was to evaluate the usefulness of AFLPs for the establishment of taxonomic relationships among the species 
of genus Arachis, and to evaluate the polymorphism among cultivars of $A$. hypogaea.

\section{Material and Methods}

\section{Plant material}

Nine morphologically diverse accessions of $A$. hypogaea, cultivated in different countries, and 19 wild species of Arachis from seven sections of the genus were analyzed (Table I).

\section{DNA extraction}

DNA was extracted from leaves, using the procedure described by Kochert et al. (1991). The DNA quality was checked in $0.8 \%$ agarose gels, and its quantity measured by

Table I - Accessions of A. hypogaea and other Arachis species analyzed.

\begin{tabular}{|c|c|c|}
\hline Section & Species name & Accession \\
\hline \multirow[t]{19}{*}{ Arachis } & A. hypogaea & \\
\hline & & PI $280688^{1}$ \\
\hline & & PI $275690^{2}$ \\
\hline & & PI $262090^{3}$ \\
\hline & & PI $268906^{4}$ \\
\hline & & PI $139914^{5}$ \\
\hline & & PI $262118^{6}$ \\
\hline & & PI $261924^{7}$ \\
\hline & & cv. GK $3^{8}$ \\
\hline & & PI $109839^{9}$ \\
\hline & A. monticola & K 30062 \\
\hline & A. ipaënsis & K 30076 \\
\hline & A. duranensis & G 10038 \\
\hline & A. glandulifera & K 30091 \\
\hline & A. diogoi & K 30001 \\
\hline & A. correntina & K 7830 \\
\hline & A. kuhlmannii & K 30017 \\
\hline & A. kempff-mercadoi & K 30088 \\
\hline & A. stenosperma & H 410 \\
\hline \multirow[t]{2}{*}{ Caulorrhizae } & A. pintoi & V 13364 \\
\hline & A. repens & PI 338277 \\
\hline \multirow[t]{2}{*}{ Rhizomatosae } & A. burkartii & H 17 \\
\hline & A. glabrata & V 11922 \\
\hline \multirow[t]{2}{*}{ Erectoides } & A. paraguariensis & V 7669 \\
\hline & A. major & V 7644 \\
\hline \multirow[t]{2}{*}{ Extranervosae } & A. macedoi & - \\
\hline & A. burchellii & V12618 \\
\hline Procumbentes & A. rigonii & G 10034 \\
\hline Heteranthae & A. dardani & G 12943 \\
\hline
\end{tabular}

Collector's and Institutional abbreviations: PI = Plant Introduction, $\mathrm{G}=$ Gregory, $\mathrm{H}=$ Hammons, $\mathrm{K}=$ Krapovickas, $\mathrm{V}=$ Valls. Origin of each accession of $A$. hypogaea: 1: Peru; 2: Brazil; 3: Bolivia; 4: Zimbabwe, 5: Zaire; 6: Bolivia; 7: Argentina; 8: USA; 9: Venezuela. using a $260 \mathrm{~nm}$ wavelength. For the AFLP analysis, the DNAs were diluted to $14 \mathrm{ng} / \mu \mathrm{L}$.

\section{AFLP analysis}

The AFLP analysis was performed following the manual of the AFLP kit (Life Technologies), with minor modifications. $250 \mathrm{ng}(18 \mu \mathrm{L}$ of the $14 \mathrm{ng} / \mu \mathrm{L}$ DNA dilution) of genomic DNA were digested for 2 hours at $37^{\circ} \mathrm{C}$, using $3 \mu \mathrm{L}$ of a mix of Eco RI and Mse I. The restriction enzymes were inactivated by heating at $70{ }^{\circ} \mathrm{C}$ for $15 \mathrm{~min}$. Eco $\mathrm{RI}$ and Mse I adapters were ligated to the restriction fragments, adding to each tube $24 \mu \mathrm{L}$ of adapter ligation solution, $1 \mu \mathrm{L}$ of T4 DNA ligase, and incubating the tubes at $20^{\circ} \mathrm{C}$ for $2 \mathrm{~h}$. A pre-amplification reaction was performed, mixing $5 \mu \mathrm{L}$ of a 1:10 dilution of the digested and ligated fragments, $40 \mu \mathrm{L}$ of pre-amp primer mix, $5 \mu \mathrm{L}$ of $10 \mathrm{X}$ PCR buffer, and $1 \mu \mathrm{L}$ of 1 unit $/ \mu \mathrm{L}$ Taq DNA polymerase, in a final volume of $51 \mu \mathrm{L}$. The following pre-amplification cycle was performed 20 times: $94{ }^{\circ} \mathrm{C}$ for $30 \mathrm{~s}, 56^{\circ} \mathrm{C}$ for $60 \mathrm{~s}$, and $72{ }^{\circ} \mathrm{C}$ for $60 \mathrm{~s}$. The pre-amplification solution was diluted to $1: 50(\mathrm{v} / \mathrm{v})$, and $3 \mu \mathrm{L}$ were transferred to a $1.5 \mathrm{~mL}$ tube containing $147 \mu \mathrm{L}$ of TE buffer. A selective amplification was performed, mixing $5 \mu \mathrm{L}$ of a mix of $5 \mu \mathrm{L}$ of labeled Eco RI primer $(18 \mu \mathrm{L}$ of Eco RI primer, $10 \mu \mathrm{L}$ of kinase buffer, $20 \mu \mathrm{L}$ of alpha ${ }^{32} \mathrm{P}, 2 \mu \mathrm{L}$ of $\mathrm{T} 4$ polynucleotide Kinase) and $45 \mu \mathrm{L}$ of Mse I primer, $5 \mu \mathrm{L}$ of a mix of $79 \mu \mathrm{L}$ of millipore water, $20 \mu \mathrm{L}$ of $10 \mathrm{X}$ PCR buffer and $1 \mu \mathrm{L}$ of Taq DNA polymerase, and $5 \mu \mathrm{L}$ of diluted preamplification solution. The selective amplifications were performed using the three pairs of primers (Eco RI - AGC / $M s e$ I - CTG; Eco RI - ACT / Mse I - CTT; Eco RI - ACC / Mse I - CTG). A touch-down cycle was performed: 1 cycle of $60 \mathrm{~s}$ at $94^{\circ} \mathrm{C}, 60 \mathrm{~s}$ at $65^{\circ} \mathrm{C}$ and $90 \mathrm{~s}$ at $72^{\circ} \mathrm{C}$; followed by 9 cycles of $1{ }^{\circ} \mathrm{C}$ lower annealing temperature each cycle, and 23 cycles of $30 \mathrm{~s}$ at $94{ }^{\circ} \mathrm{C}, 30 \mathrm{~s}$ at $56^{\circ} \mathrm{C}$ and $60 \mathrm{~s}$ at $72{ }^{\circ} \mathrm{C}$. The pre and the selective amplifications were performed in a Perkin-Elmer Thermocycler.

\section{Gel electrophoresis}

Twenty microliters of loading buffer ( $98 \%$ formamide, $10 \mathrm{mM}$ EDTA, $0.005 \%$ of xylene cyanol FF and $0.005 \%$ of bromophenol blue) were added to each tube. The PCR products were denatured by heating at $90^{\circ} \mathrm{C}$ for $3 \mathrm{~min}$, and then immediately placed on ice. Two microliters of each sample were loaded per track, and the fragments were electrophoresed in $6 \%$ acrylamide gels (20:1 acrylamide:bis; $7.5 \mathrm{M}$ urea; $1 \mathrm{X} \mathrm{TBE}$ ) for $1.30 \mathrm{~h}$ at $55 \mathrm{~W}$. The gel was transferred to a $3 \mathrm{MM}$ chromatography paper and dried in a gel drier at $80{ }^{\circ} \mathrm{C}$ for $2 \mathrm{~h}$. Gels were exposed to XOMAT X-ray film (KODAK) overnight at room temperature. 


\section{Data analysis}

The AFLP bands were scored for presence or absence in each accession. Fragments of the same size were considered to have the same sequence. A genetic distance matrix was obtained using the genetic distance described by Link et al. (1995), and used to construct a UPGMA tree. A bootstrap analysis was performed using 1,000 replicates. All analyses were performed using the TREECON computer (program) software (Van de Peer and Watcher, 1994).

\section{Results}

A total of 408 fragments were analyzed using the three pairs of primers. One hundred and eight fragments were scored in the essay performed by using the pair of primers Eco RI-ACT / Mse I-CTT, 131 with Eco RI-AGC / Mse I-CTG, and 169 with Eco RI-ACC / Mse I-CTG, with an average of 136 fragments per pair of primers used. Four hundred and six fragments were polymorphic, with an average of 135.3 per reaction. Only two fragments were monomorphic in all samples analyzed.

A total of 94 fragments were detected in the accessions of $A$. hypogaea, and only six of those fragments were polymorphic $(6.4 \%)$. Figure 1 shows a polymorphic fragment detected in A. hypogaea with primer combination Eco RI-ACC / Mse I-CTG.

The relationships among the species analyzed are shown in Figure 2. The species were grouped into three major clusters. The first cluster comprised all the species analyzed of section Arachis, the second one comprised the species analyzed of sections Caulorrhizae (A. pinto $i$ and $A$. repens), Rhizomatosae (A. burkartii and $A$. glabrata), Heteranthae (A. dardanii), Procumbentes (A. rigonii) and Erectoides ( $A$. paraguariensis, $A$. major); the third group comprised $A$ macedoi and $A$. burchellii, both of section Extranervosae. The group formed by the species of section Arachis was subdivided into three subgroups: the first one comprised all the accessions of A. hypogaea, A. monticola, $A$ ipaënsis and $A$. duranensis, the second one comprised $A$. kempff-mercadoi, A. diogoi, A. kuhlmannii, $A$. stenosperma, $A$. correntina, and the third one comprised $A$. glandulifera. The bootstrap values ranged from $24 \%$ to $100 \%$.

The two analyzed species of section Rhizomatosae did not group together. Arachis burkartii was grouped closer to $A$. pintoi and $A$. repens, while $A$. glabrata was placed closer to $A$. paraguariensis and $A$. major, both of section Erectoides.

\section{Discussion}

Four hundred and eight fragments were detected using three pairs of primers, 406 (99\%) being polymorphic, taking all the species into account. The RAPD analysis of five species of section Arachis using six primers showed an average of 19.3 polymorphic loci (Lanham et al., 1992).

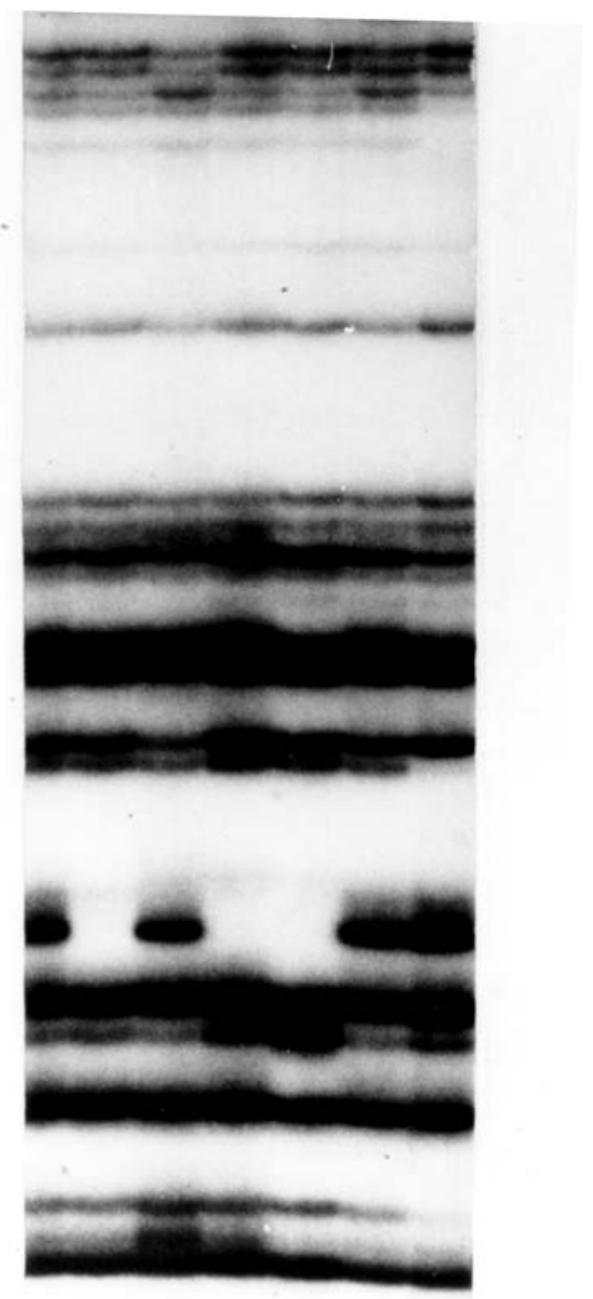

Figure 1 - Polymorphism among the accessions of $A$. hypogaea using the primers Eco RI - ACC/ Mse I - CTG.

Lanham et al. (1994) analyzed seed storage protein variation in seventy-two accessions of 22 species of sections Arachis, Erectoides, Extranervosae and Triseminatae and found a total of 24 polymorphic bands.

The results suggest that AFLP is very useful in establishing the genetic relationships among Arachis species. As a rule, the grouping of the species based on AFLP data agreed with the classification established by using morphology, geographic distribution and cross-compatibility (Krapovickas and Gregory, 1994), despite the small number of accessions analyzed of each species. AFLP data were also consistent with the existing knowledge of the systematics of other plant species (Hill et al., 1996; Paul et al., 1997).

The species of section Arachis were grouped into three clusters. The first one comprised $A$. hypogaea (AABB), A monticola (AABB), A. duranensis (AA) and $A$. ipaënsis (BB). The close relationship of the diploid species A. ipaënsis and A. duranensis with A. hypogaea is consistent with previous studies (Kochert et al., 1991; Kochert et 


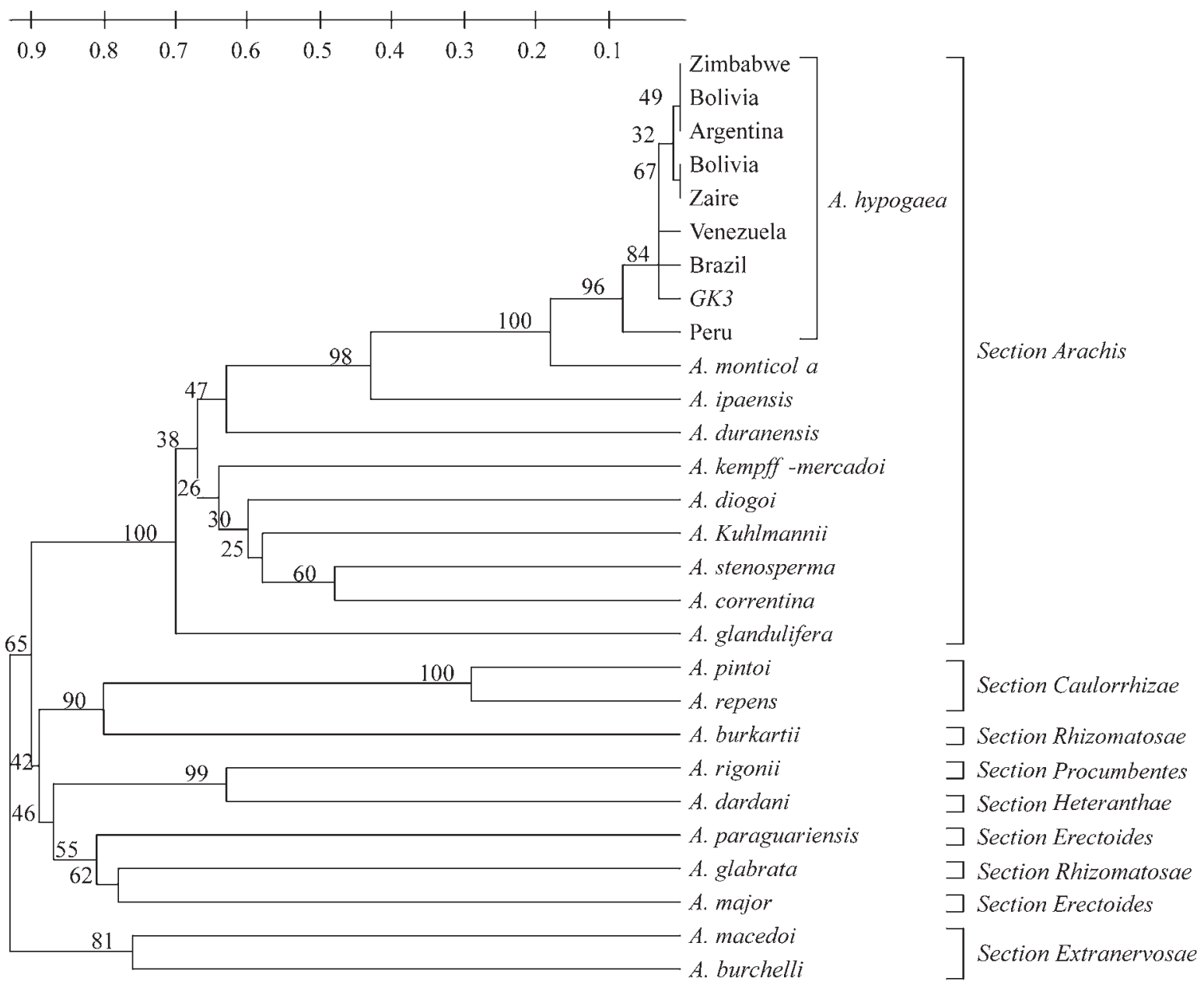

Figure 2 - UPGMA tree showing the relationships among the 20 species of seven sections of the genus Arachis.

al., 1996), which also appointed these diploid species as being the most probable donors of the genomes of $A$. hypogaea. The second group comprised the A genome species, and the third one comprised A. glandulifera, which has a D genome (Stalker, 1991). The data agreed with the cytogenetic classification, that is a good evidence of crossability among A genomes species.

The other sections with more than one species analyzed were also well characterized. Arachis pintoi and A. repens (section Caulorrhizae) were grouped very close to each other. Hybrids between A. pintoi and A. repens show a pollen fertility level of $86.9 \%$ (Gregory and Gregory, 1979). RAPD analysis of several accessions of $A$. pintoi and $A$. repens indicated that these two species are closely related on molecular grounds (Gimenes et al., 2000). The species of section Erectoides (A. paraguariensis, A. major) were grouped with A. glabrata, that belongs to section Rhizomatosae. Section Extranervosae was also characterized, having A. macedoi and A. burchellii grouped together. The exception was section Rhizomatosae, which had $A$. glabrata and A. burkartii put apart in the tree. Arachis glabrata is tetraploid, while $A$. burkartii is diploid, and it is known that the latter one does not cross with any other species of genus Arachis (Gregory and Gregory, 1979). Thus, the evidence suggests that these two species are not closely related and, along the evolution and diversification of this genus, rhizomes may have appeared independently, at least twice.

Six fragments were polymorphic in A. hypogaea cultivars. The polymorphism detected using this molecular marker is still very low, when compared to other crops. For instance, in an analysis of 14 rice accessions, $27.8 \%$ $(147 / 529)$ of loci detected were polymorphic (Mackill et al., 1996). The percentage of polymorphic markers found in A. hypogaea $(6.4 \%)$ was similar to the one found in another AFLP analysis of variation within 6 divergent genotypes from three botanical varieties of $A$. hypogaea (He and Prakash, 1997). Because $A$. hypogaea may have arisen recently from a single polyploidization event (Halward et al., 1991), it is likely that a simple nucleotide substitution, rather than gross differences in few loci, may account for the variation in the cultivated peanut (Kochert et al., 1996; He and Prakash, 1997). The microsatellite loci analysis of A. hypogaea, where alleles differed from each other in a 
few bases, showed higher polymorphism than RFLP and RAPDs (Hopkins et al., 1999). Thus, the data presented in this and in other studies indicate that techniques which allow the detection of few to single nucleotide modifications, such as SNPs (Single Nucleotide Polymorphisms), will have to be used in A. hypogaea to identify informative loci.

\section{Acknowledgements}

The participation of M.A.G. and J.F.M.V. was supported by CNPq, RHAE - Brazil.

\section{References}

Cerry TA, Caetano-Anollés G, Trigiano RN and Starman TW (1996) Molecular phylogeny and DNA amplification fingerprinting of Petunia taxa. Theor Appl Genet 92:1009-1016.

Curtis MD, Cameron DF and Manners JM (1995) Molecular evidence that diploid Stylosanthes humilis and diploid Stylosanthes hamata are progenitors of allotetraploid Stylosanthes hamata cv. Verano. Genome 38:344-348.

Fatokun CA, Danesh D, Young ND and Stewart EL (1993) Molecular taxonomy relationships in the genus Vigna based on RFLP analysis. Theor Appl Genet 86:97-104.

Galgaro L, Valls JFM and Lopes CR (1997). Study of the genetic variability and similarity among and within Arachis villosulicarpa, A. pietrarellii and A. hypogaea through isoenzyme analysis. Genetic Resources and Crop Evolution 44:9-15.

Galgaro L, Lopes CR, Gimenes MA, Valls JFM and Kochert G (1998) Genetic variation between several species of sections Extranervosae, Caulorrhizae, Heteranthae, and Triseminatae (genus Arachis) estimated by DNA polymorphism. Genome 41:445-454.

Gimenes MA, Lopes CR, Galgaro ML, Valls JFM and Kochert G (2000) Genetic variation and phylogenetic relationships based on RAPD analysis in section Caulorrhizae, genus Arachis (Leguminosae). Euphytica 116:187-195.

Gregory MP and Gregory WC (1979) Exotic germplasm of Arachis L. interspecific hybrids. J Heredity 70:185-193.

Halward TM, Stalker HT, LaRue EA and Kochert G (1991) Genetic variation detectable with molecular markers among unadapted germplasm resources of cultivated peanut and wild species. Genome 34:1013-1020.

Halward TM, Stalker HT, LaRue EA and Kochert G (1992) Use of single primer DNA amplification in genetic studies of peanut. Plant Mol Biology 18:315-325.

He G and Prakash CS (1997) Identification of polymorphic DNA markers in cultivated peanut (Arachis hypogaea L.). Euphytica 97:143-149.

Hill M, Witsenboer H, Zabeau M, Vos P, Kesseli R and Michelmore R (1996) PCR-based fingerprinting using AFLPs as a tool for studying genetic relationships in Lactuca spp. Theor Appl Genet 93:1202-1210.

Hopkins MS, Casa AM, Wang T, Mitchell SE, Dean RE, Kochert G and Kresovich S (1999) Discovery and characterization of polymorphic simple sequence repeats (SSRs) in peanut. Crop Sci 39:1243-1247.
Jain A, Bhatia S, Banga SS, Prakash S and Lakshmikumaran M (1994) Potential use of random amplified polymorphic DNA (RAPD) technique to study the genetic diversity in Indian mustard (Brassica juncea) and its relationship to heterosis. Theor Appl Genet 88:116-122.

Kochert G, Halward T, Branch WD and Simpson CE (1991). RFLP variability in peanut (Arachis hypogaea L.) cultivars and wild species. Theor Appl Genet 81:565-570.

Kochert G, Stalker HT, Gimenes M, Galgaro L, Lopes CR and Moore K (1996) RFLP and cytogenetic evidence on the origin and evolution of allotetraploid domesticated peanut Arachis hypogaea (Leguminosae). Amer J Bot 83:128211291.

Krapovickas A and Gregory WC (1994) Taxonomia del genero Arachis (Leguminosae). Bonplandia 8:1-186.

Lanham PG, Fennell S, Moss JP and Powell W (1992) Detection of polymorphic loci in Arachis germplasm using random amplified polymorphic DNAs. Genome 35:885-889.

Lanham PG, Forster BP and McNicol P (1994) Seed storage protein variation in Arachis species. Genome 37:487-496.

Link W, Dixkens C, Singh M, Schwall A and Melhiger AE (1995) Genetic diversity in European and Mediterranean faba bean germplasm revealed by RAPD markers. Theor Appl Genet 90:27-32.

Maass BL and Ocampo CH (1995) Isozyme polymorphism provides fingerprints for germplasm of Arachis glabrata Bentham. Genetic Resources and Crop Evolution 42:77-82.

Mackill DJ, Zhang Z, Redoña ED and Colowit PM (1996) Level of polymorphism and genetic mapping of AFLP markers in rice. Genome 39:969-977.

Paik-Ro OG, Smith RL and Knaulf DA (1992) Restriction fragment length polymorphism evaluation of six peanut species within the Arachis section. Theor Appl Genet 84:201-208.

Paul S, Wachira FN, Powell W and Waugh R (1997) Diversity and genetic differentiation among populations of Indian and Kenyan tea (Camellia sinensis L) O. Kuntze) revealed by AFLP markers. Theor Appl Genet 94:255-263.

Van der Peer Y and Watcher RD (1994) TREECON for Windows: a software package for the construction and drawing of evolutionary trees for the Microsoft Windows environment. Comput Applic Biosci 10:569-570.

Singh AK, Sivaramakrishnan S, Mengesha MH and Ramaiah CD (1991) Phylogenetic relations in section Arachis based on seed protein profile. Theor Appl Genet 82:593-597.

Singh AK, Gurtu S and Jambunathan R (1994) Phylogenetic relationship in the genus Arachis based on seed protein profiles. Euphytica 74:219-225.

Stalker HT (1991) A new species in section Arachis of peanuts with a D genome. Amer J Bot 78:630-637.

Stalker HT, Phillips TD, Murphy JP and Jones TM (1994). Variation of isozyme patterns among Arachis species. Theor Appl Genet 87:746-755.

Stalker HT, Dhesi JS and Kochert G (1995) Variation within the species Arachis duranensis Krap and W.C. Gregory, a possible progenitor of cultivated peanut. Genome 38:1201-1212.

Vos P, Hogers R, Bleeker M, Reijans M, Van de Lee T, Hornes M, Frijters A, Pot J, Peleman J, Kuiper M and Zabeau M (1995) AFLP: a new technique for DNA fingerprinting. Nucleic Acid Research 23:4407-4414.

Xu WW and Sleeper DA (1994) Phylogeny of tall fescue and related species using RFLPs. Theor Appl Genet 88:685-690. 